\title{
RESPONSE AND RESILIENCE: ACEH'S TRADE IN THE SEVENTEENTH CENTURY
}

\author{
Sher Banu A. L. Khan
}

One of the major impacts of the colonial era in insular Southeast Asia was the partial replacement of the indigenous trading classes by foreign and migrant merchants. An important question to be asked here is, when did this replacement process begin? Anthony Reid's contribution to the historiographic tradition of precolonial Southeast Asia-besides placing his thesis on the history of the sea in a regional Southeast Asian context-was to view the region as closely bound up with international commerce and to place it in the context of a wider maritime world. ${ }^{\prime} \mathrm{He}$ argued that, although Southeast Asians interacted as equals with Europeans in the 1600s, by 1700 the inequalities were already manifest. ${ }^{2}$ According to Reid, critical military encounters with Europeans that eclipsed some local ethnic shipping, trade decline, and loss of revenue brought about the failure of the last stand of Islamic commerce. ${ }^{3}$

During these challenging and dangerous times when indigenous polities were facing political, military, and commercial incursions from the English and Dutch East

Sher Banu A. L. Khan is an assistant professor in the Malay Studies department at the National University of Singapore. Her research interest is the Malay world and Southeast Asia in general in the early modern period, focusing on history, gender studies, and Islam.

${ }^{1}$ Anthony Reid, Southeast Asia in the Age of Commerce, Volume 2: Expansion and Crisis (Iondon: Yale University Press, 1993), 129.

${ }^{2}$ Anthony Reid, Charting the Shape of Early Modern Southeast Asia (Singapore: Institute of Southeast Asian Studies, 2000), 12.

${ }^{3}$ Reid, Southeast Asia, Vol. 2, 268-325. 
Indies companies (English East India Company, EIC; and Dutch United East India Company, Verenigde Oostindische Compagnie, VOC), Aceh was ruled by four women from 1641-99. They were Sultanah Taj-ul Alam Safiatuddin Syah (r. 1641-75), Sultanah Nur Alam Naqiatuddin Syah (r. 1675-78), Sultanah Inayat Zakiatuddin Syah (r. 1678 88), and Sultanah Kamalat Zainatuddin Syah (r. 1688-99). Prior to 1637, the ruler was the twelfth sultan of Aceh, Iskandar Muda (r. 1607-37), ${ }^{4}$ and European and indigenous scholars contend that Aceh's power began to dip after his glorious reign.

Yet if Aceh declined between 1640-99, under the women rulers, how was it possible that, in the course of the seventeenth century, Aceh was exceptionally effective in maintaining its own independence and its own trade network, and in engaging with and counteracting the Europeans? ${ }^{5}$ Indeed, not much is known about Aceh's response to the European companies' incursions and its political and commercial networks under the women sovereigns. This article questions the extent of decline of the kingdom and argues that, partly because of the Acehnese sultanahs and their style of leadership, Aceh enjoyed another fifty years of peace and prosperity. It is noteworthy that before the narrative of replacement begins there is also the narrative of resilience when encounters among local and foreign traders were typically interactions between equals - what John Wills termed "interactive emergence." 6 Placed in this context, he argued, the "long drift to European hegemony in Asia in the early modern era could be seen to be less over-determined, less a foregone conclusion, and much more multi-causal and contingent to specific contexts."7

\section{Did Aceh Decline by 1700?}

Accounts by the ulama Nuruddin al-Raniri from the 1640s sent to private European merchants, such as Thomas Bowrey, William Dampier, and Jacob de Roy, who resided in Aceh toward the last two decades of the seventeenth century, described a thriving and cosmopolitan entreport attractive to private merchants. The port of Aceh that alRaniri related in the Bustan al-Salatin (an indigenous Malay text written in 1638 in Aceh) was never quiet during Sultanah Safiatuddin's reign, being very busy with trading ships, junks, and boats from many lands. He elaborated that under her rule, food items were cheap and the kingdom was prosperous. ${ }^{8}$ Al-Raniri mentioned the important find of abundant gold deposits in several mountains during her reign and claimed that this increased her kingdom's revenue. ${ }^{9}$

\footnotetext{
4 See: Mohammad Said, Aceh Sepanjang Abad, Vol. 1 (Medan: Pengarang Sendiri, 1961), 377; Iljas Sutan Pamenan, Rentjong Aceh Ditangan Wanita (Jakarta: DJ Waringin, 1959), 35-36; Anthony Reid, "Female Roles in Pre-Colonial Southeast Asia," Modern Asian Studies 22, 3 (1988): 641; Merle C. Ricklefs, A History of Modern Indonesia since c. 1300, second ed. (London: McMillan Press, 1993), 36; and Leonard Andaya, Kingdom of Johore 1641-1678 (Kuala Lumpur: Oxford University Press, 1975), 56.

5 J. E. Wills, "Maritime Asia, 1500-180): The Interactive Emergence of European Domination," American Historical Reviezo, February 1993: 98. Although Wills made this claim, he did not explain why. Reid stated that although Aceh witnessed a military and political decline while under the four queens, Aceh nevertheless remained as the most independent port in island Southeast Asia. See Reid, "Female Roles in Pre-Colonial Southeast Asia," 641.

${ }^{6}$ Wills, "Maritime Asia," 83.

${ }^{7}$ Ibid., 83-84.

${ }^{8}$ Siti Hawa Haji Salleh, ed., Bustan al-Salatin (Kuala Lumpur: Dewan Bahasa dan Pustaka, 1992), 43.

${ }^{9}$ Ibid., 63.
} 
In the 1670s, Bowrey described numerous traders and craftsmen frequenting the port of Aceh, such as the English, Dutch, Danes, Portuguese, Chinese, Malabarese, Bengalese, Gujeratis, Javanese, Malays, and Makassarese.$^{10}$ In the two years Dampier was in Aceh (1688-89), he found Aceh to be the largest, richest, and most populous port on the Isle of Sumatra. ${ }^{11}$ Aceh's harbor was seldom without at least ten to fifteen ships from different nations. Food was abundant and cheap, and he mentioned that rice, which was usually imported, had recently been cultivated locally. Aceh was a cosmopolitan city favored by many foreigners, such as the English, Danes, Portuguese, Gujeratis, and Chinese. Dampier made a special note of the Chinese traders, whom he described as "remarkable."12 In the 1690s, de Roy wrote about the thriving port city of Aceh, where some one hundred European vessels came each year as well as a great number of native vessels. De Roy rated Aceh as the best place in the East Indies to make one's fortune. ${ }^{13}$ The Acehnese themselves were reputed to be richer than most because of the presence of goldmines and frequent visits by wealthy foreigners. De Roy attested that as late as the 1690s, gold was still exported in large quantities from three excellent goldmines. ${ }^{14}$ The largest ships carrying merchandise to Aceh were emptied in the course of three months due to the high demand for goods and Acehneses' wealth, with every article being sold promptly and paid in ready money or gold dust. ${ }^{15}$

These testimonies do not paint a picture of a declining kingdom, but rather describe one that was remarkably resilient, able to maintain its own indigenous regional network of Muslim and non-Muslim, foreign, and local traders, and to retain its cosmopolitan identity. This article argues that although Aceh was under constant pressure from the VOC and EIC throughout the century, a few reasons explain Aceh's success in meeting these challenges. These include the limited success of the VOC in establishing its trade monopoly in the northern Straits of Melaka, the EIC's reluctance to challenge the Dutch and get involved in local politics, the resilience of the traditional Asian commercial networks and private European merchants in rivaling the European companies, and the policies of the sultanahs of Aceh and their style of leadership that provided an effective response to European encroachments in the course of the seventeenth century. Aceh remained as the last Muslim stronghold and did not succumb to any European power until 1903.

\section{Response to the Dutch: Resilience of the Aceh-Perak Tin Trade}

One main product coveted by traders and a main export of Aceh was tin. The tussle between Aceh and the VOC over control of the tin trade in Perak was long and drawn-

\footnotetext{
${ }^{10}$ Thomas Bowrey, Geographical Account of Countries Round the Bay of Bengal, 1669-1679, ed. Sir Richard Carnac Temple (London: Hakluyt Society, 1905), 286.

${ }^{11}$ Dampier noted about seven to eight thousand houses in the city alone. See William Dampier, Voyages and Discoveries, Vol. 2., ed. N. M. Penzer (London: Argonaut Press, 1931), 84-89.

12 Ibid., 95.

${ }^{13}$ British Library, India Office MSS Eur/Mack(1822/5), Voyage Made by Jacob Janssen de Roy to Borneo and Atcheen, 1691, 356, 363.

${ }^{14}$ See Dampier, Voyages and Discoveries, 84-89. See also Voyage Made by Jacob Janssen de Roy to Borneo and Atcheen, 356.

${ }^{15}$ Ibid., 361.
} 
out, but I contend that it was a contest between equals, one in which the Dutch did not meet with much success by 1700 . The VOC's main strategies to control the tin trade on the peninsula were to pressure the tin-producing areas to sign exclusive VOC contracts and, when necessary, blockade producers from dealing with anyone else. From 1642 45, the VOC failed to get a contract to procure tin from Perak. Frustrated, Antonio Van Diemen, Batavia's governor-general, blockaded the Perak River in 1644 and 1645, allowing only Aceh and Perak vessels to pass. This blockade was ineffective, however. Perak and Aceh vessels continued to bring tin from Perak to Aceh, where traders from India, willing to pay high prices, bought the tin and transported it to the western parts of Asia. Two years on, the Dutch obtained not more than ten bahar of tin from Perak, while the Indian traders obtained fifteen-hundred bahar. ${ }^{16}$

In December 1647, Jochum Roelofszoon Van Deutecom was sent to Aceh to address what Dutch officials described as the alarming situation whereby the Acehnese were making extraordinary profit. ${ }^{17}$ They complained that the Acehnese allowed Muslim traders access to trade and tin in Perak and had shut out the Dutch. ${ }^{18}$ The Dutch, however, at that point in time, had no legal recourse to stop traders from trading in Perak and Aceh who had not signed a contract with the VOC. The blockade of the Perak River, following the injunctions of the General Instruction of the Heeren Zeventien, was undisputedly illegal. In 1649 a treaty was signed ${ }^{19}$ that stipulated that Muslims traders from Surat, Bengal, and other places must leave Aceh, Perak, Kedah, and Ujong Salangh or their ships would be seized and confiscated by the Dutch. ${ }^{20}$ The Dutch blockaded the Aceh River on the pretext that Indian Muslim traders had to be kept out of Aceh and other tin-producing areas.

Pressured in this way, a contract was then signed between Sultanah Safiatuddin and VOC representatives on August 15, 1650. She promised to exclude all other traders in Perak except for the Acehnese and the Dutch. She agreed to allow the fixing of the price of tin at 311/4 in spetie (silver) per bahar (the market price fluctuated between 31 and 43 per bahar). ${ }^{21}$

Another treaty was signed in 1655 between Aceh, Perak, and the VOC with similar stipulations. Five years later, the treaties signed still remained on paper. The company pressed for another treaty and this was duly signed in 1659 between Aceh and the VOC. ${ }^{22}$ The same provisions were reiterated, in addition to the VOC's demands for exclusive nation treatment (Perak would trade only with Aceh and the VOC) and half

${ }^{16} \mathrm{~J}$. E. Heeres and P. A. Tiele, eds., Bouwstoffen voor de Geschiedenis der Nederlanders in den Maleischen Archipel (The Hague: M. Nijhoff, 1886-1895), i. "Bahar" is a Malay measure of weight varying from 210 to 230 kilograms (about $470-500$ pounds).

${ }^{17}$ Nationaal Archief (NA), f.733R. Memorije voor den E. Jochum Roeloffs van Deutecum Raat van Indie gaende de legatie aende Coninghinne van Atchin met de jachten Zeerob, ijrslingen ende de fluijt den Engel over Malacca waer naer sijn E. Sich sal hebben te reguleren.

${ }^{18}$ Ibid., f.733V.

${ }^{19}$ This treaty was signed on September 18,1649, between VOC and the Mughal governor of Surat, Miermosa. See Sinnappah Arasaratnam, "Some Notes on the Dutch in Malacca and the Indo-Malayan Trade 1641-1670," Journal of Southeast Asian History 10, no. 3 (December 1962): 487.

${ }^{20}$ Heeres, Bouwstoffen, lii.

${ }^{21}$ NA, f.315R. Origineel rapport van den oppercoopman Johan Truijtman.

22 J. E. Heeres and F. W. Stapel, eds., Corpus Diplomaticum Nerlando-Indicum, ('s-Gravenhage: M. Nijhoff, 1907-1955), 151-55. 
of the tin produced (the other half to be shared with Aceh). Again, the mixture of diplomatic pressure and blockades failed, in actuality, to secure the tin trade for the VOC, and it failed to get the stipulated amount of tin. In 1660, the ship Alkmaer brought 122 bahar of tin to Melaka, but Aceh obtained 585 bahar. ${ }^{23}$ Even the English envoy, Henry Garry, who came to Aceh from Surat bearing presents for the sultanah, was given 200 bahar of tin as a parting gift. ${ }^{24}$ Moreover, due to the geography of the region, where numerous networks of streams flow out to sea, smugglers easily moved tin to the profitable markets of Aceh and Kedah. In 1663, the VOC was forced to pay about $34-36$ reals per bahar as against the 30 reals specified in the treaty, simply because the Acehnese bid as high as 42 reals. $^{25}$

By the turn of the century, the VOC had to admit defeat in its effort to monopolize Perak's tin trade. In 1681, the Dagh-Register recorded that the VOC's trade had dwindled. By 1680, as a result of peace between the English and the Dutch, competition was further heightened by the English interest in tin, besides the perennial problem of rivalry from the local, Indian, and Portuguese traders. By this time, these traders were undercutting the Dutch at will, ${ }^{26}$ and "smuggling" had become rampant in Aceh and Kedah. ${ }^{27}$ The scourge of piracy in the 1690s compounded these problems when, in 1689, Panglima Kulup, deemed to be a pirate, burnt the Dutch redoubt in Dinding Island. ${ }^{28}$ The VOC withdrew its blockade at the mouth of the Perak River in 1689 because it served no useful purpose. ${ }^{29}$ After the Dutch departure in 1690, Perak was free from trade restrictions and outside threats. ${ }^{30}$

\section{Overlord-Vassal Relations under Sultanah Safiatuddin Syah}

One main reason for the resilience of the Aceh-Perak tin trade and the success of Perak in resisting Dutch pressures was that Perak had a protector in Aceh as its overlord and Aceh had important leverage against the VOC for the trade in Perak on the basis of its overlord rights. The sultanah's accommodative policy did not give the VOC any excuse to go to war with Aceh, which meant that it had to continue to negotiate for treaty concessions and accept compromises. Perak was able to benefit from this situation since Perak was able to avoid signing a contract with the VOC until 1650, because the sultan of Perak explained that, as a vassal of Aceh, he could not sign any contract with the VOC until he obtained permission from the sultanah of Aceh.

According to Barbara Andaya, the history of Perak in the seventeenth century was one dominated by Perak's failed search for a new, powerful friend, a search for a new

\footnotetext{
${ }^{23}$ Richard O. Winstedt, "A History of Perak," Journal of Malayan Branch of Royal Asiatic Society 12 (1934): 31.

${ }^{24}$ Ibid.

${ }^{25}$ Ibid., 34.

${ }^{26}$ G. W. Irwin, "The Dutch and the Tin Trade of Malaya in the Seventeenth century," in Studies in the Social History of China and Southeast Asia, ed. Nicholas Tarling and Jerome Ch'en (London: Cambridge University Press, 1970), 286.

${ }^{27}$ Winstedt, A History of Perak, 52.

${ }^{28}$ Barbara Andaya, Perak, the Abode of Grace: A Study of an Eighteenth-Century Malay State (Kuala Lumpur and New York: Oxford University Press, 1979), 50.

${ }^{29}$ Irwin, "The Dutch and Tin Trade of Malaya," 287.

${ }^{30}$ Barbara Andaya, Perak, Abode of Grace, 52.
} 
relationship that would replace the existing one with Aceh. Vassalage had brought no benefits, and with Aceh's perceived decline it could no longer enforce its former control. ${ }^{31}$ On her part, Sultanah Safiatuddin did sign away some trade privileges and revenues, but this did not mean that she was weak or that Aceh was in decline, since her policy of accommodation ensured that the Dutch had no excuse to attack Aceh and Perak. Although she granted the VOC exclusive nation treatment and a fixed price for tin, she did not grant the VOC toll-free privileges in Perak. The VOC insisted on such a concession, but the sultan of Perak objected, since this was his and his orangkaya's (local political-economic elite) main source of revenue. As such, according to Safiatuddin, granting toll-free privileges would be tantamount to "taking the bread out of her subjects' mouths." 32 She also refused to establish a minimum quota for the amount of tin the VOC could obtain from Perak. In Perak, she allowed only an equal sharing of tin between the VOC and Aceh.

This overlord-vassal relationship conducted by Sultanah Safiatuddin was akin to a patron-client one, that is, symbiotic and mutually beneficial. It was unlike the predatory and exploitative vassal-overlord arrangements enacted under her predecessors. During Iskandar Muda's reign, the incentive for Acehnese control over the west coast of Sumatra was, as in earlier times, pepper and gold. Iskandar Muda stationed panglimas (governors), of Acehnese origin, at the main centers of production and export: Tiku, Pariaman, Salida, and Inderapura. Under a harsh system whereby Iskandar Muda claimed 15 percent of the gold and pepper produced and fixed the price of the rest, the success of this monopoly depended on the panglimas and how harshly they were punished for disobeying Iskandar Muda's orders. The centralizing and despotic policies of Iskandar Muda and later Iskandar Thani toward their vassals in the provinces drove local elites to search for another patron. As early as 1619, some local elites along Sumatra's west coast offered to transfer allegiance to the VOC in return for protection and freedom from the Acehnese yoke. The futile attempt by the ruler of Inderapura to seek Dutch protection is an example..$^{33}$

Europeans, meanwhile, traded only at Kota Raja (Banda Aceh) under royal license. Exclusive privileges and permission to trade elsewhere were extremely difficult to secure. This resistance to European companies' pressure gave the illusion that Aceh was strong under Iskandar Muda and Iskandar Thani, and that, by comparison, Safiatuddin was weak in accommodating the West. Yet it was her predecessors who provided the initial inroads into Sumatra's west coast, paving the way for a deeper penetration of Dutch influence and control.

According to Kathirithamby-Wells, Iskandar Muda resisted the pressure of European powers for commercial concessions and thus preserved his empire from the inroads of colonial exploitation up to 1629, when Aceh was defeated at the hands of the Portuguese during the siege of Melaka. In 1632, desperate for an alliance against the Portuguese, he signed away to the Dutch some of the very concessions that he had prudently withheld for so long. By this agreement, Iskandar Muda allowed the Dutch

${ }^{31}$ Ibid., 48.

${ }^{32}$ NA, f.185R, Rapport substantieel van der oppercoopman Johan Truijtman.

${ }_{33}$ J. Kathirithamby-Wells, "Acehnese Control over West Sumatra up to the Treaty of Painan, 1663," Journal of Southeast Asian History 10, no. 3 (1969): 460. 
toll-free trade for an unspecified number of years in the whole kingdom, including Sumatra's west coast, plus freedom to participate in the Perak tin trade.

Similarly, in 1638, in his desire to get Dutch support in his war against Portuguese Melaka, Iskandar Thani verbally granted the VOC exclusive trade for an indefinite period in addition to other privileges, which constituted a surrender of royal prerogatives. ${ }^{34}$ The west coast pepper collected as tribute by the sultan could henceforth be fetched directly by the Dutch and paid for at the capital. Similarly, payment for the remaining pepper was no longer to be made locally, but at Aceh. The local elite did not welcome this change at all. Those at Tiku, Pariaman, and Inderapura resisted the delivery of pepper unless the king's tolls and duties were paid locally. The inability of the Dutch traders to produce a written document from Iskandar Thani was the only pretext by which the local elites could deny the VOC's demands. ${ }^{35}$ While Iskandar Thani's refusal to sign a contract formalizing his promises of concessions exasperated the Dutch and made them suspicious of him, his courting of the Dutch through these verbal agreements did not endear him to the local elites, either. Worse, Iskandar Thani's sudden reversal of policy and his retraction of the promise to be the Dutch's ally in their attack on Portuguese Melaka in 1641 not only brought Aceh-Dutch relations to a dangerously hostile level, but the concessions he promised to the Dutch in 1638 made Aceh open and vulnerable to Dutch commercial control.

In contrast, Sultanah Safiatuddin did not sacrifice Aceh's or her vassals' interests in exchange for Dutch alliance. Yes, she concluded many treaties with the VOC and EIC, which is to say that she that she adapted to these new instruments of peace and commerce in international diplomacy. Yet she granted only limited concessions for definite periods, thereby arresting European commercial penetration. In managing officials from the European companies, the women rulers of Aceh preferred soft power to confrontation. This was a key feature that helped explain how Aceh was able to protect its own trade and proved resilient in the face of aggressive European commercial incursions.

\section{EIC Hesitation and Lost Opportunities}

The EIC's attempt to establish and secure itself around the region of the Straits of Melaka, in the seventeenth century, was not a successful one. Numerous opportunities were presented for the EIC to increase its influence in Aceh and along Sumatra's west coast, yet those were not seized by the English. As early as 1602, Sultan Alauddin Riayat Syah showed his preference for the English rather than the Dutch, since he was impressed that the English had defeated the Spanish armada. The sultan granted to the English, via their representative James Lancaster, free entry and trade, exemption from some customs, assistance in cases of shipwrecks, protection of English property, and certain immunity from local authorities (in some cases the English could administer their own justice for English misdeeds). Despite these generous concessions, however, Lancaster decided not to set up a factory (i.e., trading post) in Aceh, preferring instead

${ }^{34}$ J. Kathirithamby-Wells, "Acehnese Control over West Sumatra up to the 1663 Treaty of Painan," International Conference on Asian History, paper no. 87, Kuala Lumpur, 1968, 465.

${ }^{35}$ Ibid. 
Priaman (on the west coast) and Bantam, where pepper was cheaper and the terms of trade more favorable. ${ }^{36}$

In 1609, Sultan Iskandar Muda granted Samuel Bradshaw, the English representative, the right to trade in Aceh. Again, the English chose not to set up a factory. At about this time Bradshaw compiled a valuable report about the patterns of Acehnese trade, in which he observed that the most valuable medium of trade in Aceh was Indian cloth from Surat, Coromandel, and Bengal, and that it was not easy for the English to penetrate this network, since India, Aceh, and Sumatra's west-coast ports already formed integral parts of a well-established trading pattern. ${ }^{37}$

In 1629, when Iskandar Muda lost much of his armada during the attack on Portuguese Melaka, it was the VOC that was able to make inroads into local politics by promising to help him attack the Portuguese. In 1631, the English decided to withdraw from Aceh. Iskandar Muda then honored Dirck Stadtlander, the Dutch commissioner, with a grand welcome at court when he arrived in Aceh in 1632, and gave him the old English factory in appreciation for the Dutch offer of assistance. ${ }^{38}$ By 1634, the English could no longer ally with the Acehnese against the Portuguese in any event, due to the signing of a convention in 1634 that ended the British struggle against the Portuguese. Thus, by the 1630s, the balance of power was slowly favoring the Dutch.

In contrast to the VOC's willingness to be engaged in local politics in order to systematically control trade in the region, the English were much less willing to do so until after the 1680s. The English were also cautious not to allow an Anglo-Dutch rivalry to break out into open warfare. In contrast, English private traders were much more influential and conducted lucrative business in Aceh and the northern half of the Straits of Melaka between Aceh, Kedah, Pegu, and Tenasserim. Besides the private European traders, the EIC and VOC faced tough competition from well-established and experienced Asian merchants, especially Indian traders, until almost the end of the seventeenth century.

During Sultanah Safiatuddin's reign, she ensured that Aceh did not make enemies and tried to balance and accommodate both the Dutch and the English, depending on contexts. The EIC decided to make a comeback in 1643, when the ship HMS Supply anchored in Aceh's harbor and Walter Clarke, the EIC's representative, went on shore to make his presentation to the sultanah. He managed to have an audience with her and her orangkaya, and the sultanah allowed the English to build a factory in Aceh. However, the English reported that they, together with the Dutch, faced stiff competition, especially from the Gujerati merchants and from other Indian merchants from Bengal, Masulipatam, and Pegu, and thus they had scarcely any funds left. ${ }^{39}$ The English and Dutch complained about trade rivalry from other local traders, too, such

${ }^{36}$ Ashin Das Gupta, Aceh in Indonesian Trade and Politics 1600-1641 (doctoral dissertation, Cornell University, 1962), 60. Pepper was selling at an unusually high 64 reals per bahar in Aceh when, at other markets, pepper was selling for only about 25-35 reals/bahar. The intense competition among the English, Dutch, French, and Danes - plus a bad harvest in 1602-caused the price of pepper to shoot up in Aceh.

37 Ibid., 126.

${ }^{38}$ Ibid., 175.

${ }^{39}$ William Foster, The English Factories in India 1618-1669 (Oxford: The Clarendon Press, 1927), 130. 
as those from Johor and Macassar. From 1642-45, the English complained about the many Asian ships found in Aceh, which rendered trade for the English to be "dull."4"

For the next five years, the market was still unfavorable to the English. The sultanah favored the Dutch rather than the English due to the Dutch's strong influence in the Straits, especially after capturing Melaka in 1641. However, while accommodating the VOC and the EIC, the sultanah was careful to continue to oblige and support the Asian and private merchants who had traded in Aceh since her predecessors' time, especially the Gujeratis. (Once a Courteen ship seized two Surat junks in Aceh's harbor and threatened to confiscate them unless a ransom was paid. The sultanah reacted swiftly by imprisoning the Courteen factors until they repaid the Surat merchants for their losses. ${ }^{41}$ ) By August 21, 1649, the English realized that they had failed to make inroads in Aceh and the English factory in Aceh was thus dissolved. ${ }^{42}$

In December 1660, the English made another attempt to trade in Aceh. Henry Gary was sent in the ship HMS Welcome to negotiate trade with the Sultanah Safiatuddin. This attempt was partially successful, inasmuch as Gary secured a grant of privileges from the sultanah, but, again, the English were not able to compete with the Dutch. Letters dispatched to Aceh intimated that no further investment in Aceh was contemplated, as the prospects for the English were so poor. The Dutch, on the other hand, the English noted, were doing well along Sumatra's west coast, since they were lading twenty ships every year with pepper. ${ }^{43}$

In 1661, just when the English were once again deciding to withdraw from Aceh, the sultanah changed her stance from favoring the Dutch to actively courting the English, instead. The Dutch use of force to obtain tin from Perak angered the Acehnese elite and, in Perak, the situation came to a head with the massacre of VOC officials in 1651.

Ten years after, compensations promised to the Dutch were still not forthcoming, and the Dutch were impatient with the small amounts of tin they could obtain (despite the contract granting them half of the tin that was sent to Aceh). The VOC was of two minds as to how to deal with the Acehnese and to increase its share of the tin trade. The hardliners, such as Arnold Vlamingh, wanted to go to war with Aceh, but this was not approved by VOC's governor-general and the Heeren Seventeen (a controlling body of seventeen VOC shareholders representing different enterprises). The Dutch instead decided to close their factory in Aceh. This alarmed the sultanah and her orangkaya tremendously, since they saw this as a first step to war. The sultanah quickly wrote to King Charles II on October 12, $1661 .{ }^{44}$ She recalled how when Henry Gary arrived in Aceh in 1660 to negotiate trade, she had allowed him to construct a warehouse at the port, English merchants were allowed to trade in Aceh, and three English ships a year

${ }^{40}$ Ibid., 146.

41 Ibid., 170.

${ }^{12}$ Ethel Bruce Sainsbury, A Calendar of the Court Minutes etc. of the Governour and Company 1635-1639 to

1677-1679, 11 volumes (Oxford, Clarendon Press, 1907-1938), Vol. 3 (1644-49), 262.

"Foster, The English Factories, 75.

"For the letter in Malay, see Teh-Ananbel Gallop, "Gold, Silver, and Lapis Lazuli: Royal Letters from Aceh in the 17th Century," unpublished paper presented at the First International Conference of Aceh and Indian Ocean Studies, Banda Aceh, February 24-26, 2007. 
had been granted permission to trade in Aceh and its dominions. But instead, she further observed, the English merchants had been driven off by the Dutch. The "accursed" (celaka) Dutch, she wrote, apprehended his subjects, and that was why the English were unable to trade in her dominions. She beseeched Charles II to safeguard the English traders from harm.

In the 1660s, trade rivalries between the English and Dutch companies increased, as reflected in the number of complaints and petitions put forward by the EIC to the Council of Trade. The December 11, 1660, entry of Court Minutes of the EIC mentioned a close trading link between the company and the Queen of Aceh, but the English were not able to take advantage of this link because the Dutch were continually molesting the English factors, factories, and traders, and hence the EIC requested that the king intercede. ${ }^{45}$ This entry verified the sultanah's claims that the Dutch were actively harassing the English in Aceh. In another entry there was a complaint by the owners of the HMS Bantam that the Dutch prevented them from loading pepper on board the ship although there was a contract made with the Queen of Aceh that permitted the lading. ${ }^{46}$

The English took three years to reply to the sultanah's letter. Given the privileges granted by the sultanah, they calculated that trade would now probably yield great profit. The Dutch had generally made more significant inroads into local commercial and political affairs in the Indies than had the English. But as a result of Sultanah Safiatuddin's policy of keeping Aceh's trade open to all nations, which resulted in the uneasy checks and balances between the English and the Dutch, Aceh remained independent of both powers. Furthermore, since the Dutch were not gaining much from Aceh, the Dutch had decided to close their factory there in 1663 and concentrated their commercial efforts on Sumatra's west coast instead. Whether this was the main catalyst for the English response could not be ascertained, but the EIC responded to the Sultanah's 1661 invitation by sending the HMS Vine to Aceh on April 29, 1664. Tragically, this delegation came to a speedy and disastrous conclusion when the ship capsized and sank. Francis Cobb and Richard Taylor, two English representatives aboard, drowned, and only Henry Gary was saved. ${ }^{47}$ Despite this setback, on August 31, 1664, a letter from Madras stated that the company was proposing to send the HMS Hopewell to Aceh to keep possession of the house and ground purchased from the Queen.

The years 1665-67 saw the outbreak of war in Europe between the English and the Dutch. This resulted in a considerable dislocation of overseas trade and a decrease in factory output. The Treaty of Breda (July 1667), which terminated the war, was a disappointment to the English. Under its terms, each nation retained the places it had captured. The English, having been reluctant to get involved politically in the region prior to this, lost out. From 1671-73, the EIC and VOC's affairs were again overshadowed by war between England and Holland. When another peace treaty was signed on February 14, 1674, the two companies once again agonized over their

${ }^{45}$ Sainsbury, A Calendar of the Court Minutes, Vol 6, 56-60.

${ }^{46}$ Ibid., 64-65.

${ }^{47}$ Foster, The English Factories, 322-23. 
overseas trade and possessions, the safety of their ships, settlement terms, and old grievances.

Despite the EIC's hope and desire to continue to have a presence in Aceh, it was only in the 1680s that it made some headway in Sumatra. The main reason was, after eighty years of having a settlement in Bantam, the English lost their footing in the region and also their largest single source of pepper. ${ }^{48}$ Under VOC Governor-General Cornelis Speelman, Bantam was captured by the Dutch in March 1682.

The EIC directors wrote a letter to the Queen of Aceh, Sultanah Zakiatuddin Syah, dated October 1, 1684, requesting permission to trade in Aceh once again and to build a fort. ${ }^{49}$ Given the increased success of the Dutch in capturing local ports - such as Makassar in 1669 and Bantam in 1682-the English reasoned that the only free port left was Aceh, and they saw the need to fortify Aceh to protect the EIC's assets. The Madras Council sent two representatives, Ralph Ord and William Cawley, on the HMS Rochester to Aceh, where they stayed from October to December $1684 .{ }^{50}$ Following her predecessor's policy of welcoming all nations and not subjugating Aceh to any one power, Sultanah Zakiatuddin replied that the English were welcome to trade, but not to build a fort, since doing so was prohibited by the inviolable rules of the kingdom. She added that, even if the president of Madras had filled her kingdom with gold, she could not grant him permission to build a stone fort. The sultanah also did not exempt the English from paying custom dues, which were the kingdom's main revenue. As a result, the English reasoned that they would not be able to turn a profit, and it was unlikely that they'd ever be allowed to build a fort. Therefore, in the mid-1680s, despite the Acehnese willingness to forge better relations with the English and the English themselves being keen and determined to set up in Aceh, the attempt was still botched.

Failing in Aceh, the English company's aim to fortify and build a settlement in Sumatra was not totally lost. The EIC had two other sites from which to choosePriaman and Tiku. However, in the end it acquired instead a place much farther south of Aceh, in Bengkulu (Bencoolen), an unknown and undesirable place, but where the English first formed a base in South Sumatra and where they remained until 1824, when they exchanged it with the Dutch for Melaka in the Anglo-Dutch Treaty of 1824.

\section{Resilience of Traditional Asian Traders and Private European Merchants}

Arasaratnam notes that the main development in the Indian Ocean in the seventeenth century was the marked expansion of Indian maritime commerce. The three great Islamic empires - the Ottoman, the Safavid, and the Mughal-continued to assure reasonable protection to traders, thus consolidating the deep penetration of the continent by trade, which had begun a century earlier.

${ }^{48}$ Anthony Farrington, "Negotiations at Aceh in 1684: An Unpublished English document," Indonesia and the Malay World 27, No. 77 (1999): 19.

${ }^{49}$ India Office Records, IOR: E/3/90 f.376. Letter dated March 16, 1684, from London to president and council at Fort St. George.

${ }^{50}$ IOR: E/3/44, ff. 171-81. This diary of Ord and Cawley has been reproduced in Farrington, "Negotiations at Aceh in 1684." 
This ancient Indian maritime commercial network continued to be resilient in Aceh as the port of call for Indian traders in the course of the same century. Mughal royalty, such as Emperor Aurangzeb and Dara Shukoh, participated in Aceh's trade, and Aurangzeb sent a delegation to Aceh and exchanged presents with Sultan Iskandar Thani in $1641 .{ }^{51} \mathrm{An}$ account found in the Bustan al-Salatin illustrates Sultanah Safiatuddin's policy of favoring and protecting Asian merchants, as mentioned above. The Bustan relates that when the sultanah's husband, Sultan Iskandar Thani, died, the Gujerati delegation that was in Aceh expressed disappointment, since the delegates believed that what was promised to them by Iskandar Thani would now not be realized. They were proven wrong, however, when the dead sultan's successor, his widow, decreed to her ministers that the Gujerati delegates be granted exactly what was promised to them without a single change. Not only did the sultanah keep her late husband's promises, but she also presented the Gujerati delegates with eight elephants. (One of these in particular deserves a special mention, because it had four tusks!) Never before, relates the Bustan, was there a more generous grant given to any delegation. Not surprisingly, the Bustan mentions that the Gujerati delegation was especially grateful to the sultanah and went home happy. ${ }^{52}$

The Dutch faced tough competition from the Indian traders in Aceh and Perak over the tin trade and, in Sumatra's west coast, over the pepper trade. When the Dutch closed their factory in Aceh in 1663 and reports from Dutch factors in Aceh dwindled, the EIC merchants continued to report tough competition from Surat traders in Aceh well into the 1680s. They reported that Aceh abounded with tin, gold, elephant teeth, Benjamin camphor, cassia, lignum, logwood, pepper, and other commodities that were in demand in India. The English noted that, despite the offers from Sultanah Safiatuddin in 1661, they had not grasped the opportunity to establish a trading post in Aceh. This was partly due to the inability of the English to compete with the Surat merchants who sold cloth and bought pepper in Aceh. ${ }^{53}$ As noted above, in 1684 Ord and Cawley reported that the English would not be able to pay for the upkeep of a factory let alone finance a fort, since pepper and other goods brought into Aceh were bought by Surat merchants at higher rates than the English would ever pay. The English also noted that when these Surat merchants brought cloth to sell, the price of the commodity fell and the English could sell very little.

In 1685, following the Ord and Cawley delegation, the president of Fort St. George sent John Pitt and Thomas Constable to Aceh with a reply to the Sultanah's Zakiatuddin's letter and the company's returned gifts. Pitt reported that the prices for rice and cloth, two commodities the English hoped to supply and sell in Aceh in return for pepper and gold, were low. ${ }^{54} \mathrm{He}$ observed an unusually large number of ships, not fewer than thirty sails, in Aceh's harbor, and concluded that the competition for goods had lowered the price of rice to twenty-two bamboos per mas (Malay currency) from

51 Sinnappah Arasaratnam, Maritime India in the Seventeenth Century (Delhi: Oxford University Press, 1994), 67.

52 Teuku Iskandar, ed., Bustan Us-Salatin (Kuala Lumpur: Dewan Bahasa dan Pustaka, 1966), 59-60.

${ }^{53}$ IOR: E/3/90 f.445, Letter Book 7 (1682-85).

${ }^{54}$ Rice was selling for sixteen bamboos per mas, while the usual selling rate was between four to eight bamboos. 
the common market price of four to eight bamboos per mas. ${ }^{55}$ Pitt's report was supported by an entry in the Diary and Consultation Book, which gave an account of the bad markets for the English in Aceh. ${ }^{56}$

While the EIC failed to capitalize on the sultanah's overtures, English private merchants were quick to seize opportunities. In October 1664, Edwards Winter, a powerful English private merchant who had been trading between Aceh, Kedah, and Ujong Salang, decided to take the initiative to protect and preserve an English interest in Aceh. He sent a Mr. Widdrington to Aceh to keep the English factory there going. Although he was chided by the EIC's Surat Council, which told him in no uncertain terms that the Aceh factory was entirely the company's concern and Winter had no business to interfere, he was undeterred. ${ }^{57}$ Indeed, he paid no attention to Dutch warnings, either, when they went to war against Siam and Aceh and announced that no English vessel would be allowed to trade in either country. Winter argued that the Dutch had no right to prevent the English from trading in any port where there already was an English factory. ${ }^{58}$

Thus, while the EIC factors could not make much headway in Aceh, private English merchants had a lucrative stay in Aceh from the late 1680s to the end of the century. In 1687-88, Siam, under King Narai, underwent a revolution that caused foreigners to flee. When the Mergui massacre occurred in July 1687, English traders and adventurers were expelled from Siam, and one of the places they escaped to was Aceh. Examples were merchants such as Francis Delton and Tyler. ${ }^{59}$ Both William Dampier and Charles Lockyer observed that there was a resident, semi-autonomous English community in Aceh. William Soames, who resided in Aceh in the 1690s, even became the semi-official EIC correspondent and resident. Besides these Englishmen, mention has also been made of Captain Thomas Oyles and Mr. Walsh. Besides trading, these men served as sources of information for EIC officials and sometimes carried letters and papers with them for delivery to designated places. Walsh even made presentations to the sultanah and received gifts in return. ${ }^{60}$

These reports, in addition to the accounts mentioned earlier by other English and Dutch private traders (e.g., Bowrey, Dampier, and de Roy), illustrated that Aceh continued to be a busy and lucrative port for both European and Asian traders, ensuring the survival of local and regional trading networks.

\section{Women Rulers: From Predatory to Protective Rule}

John Villiers argued that one important effect of the highly political character of commerce in Southeast Asia was to impede the development of capitalism. Since trade

\footnotetext{
${ }^{55}$ Diary and Consultation Book of Fort St. George 1693-1695, vol. 22 (Madras: Superintendent, Govt. Press, 1910-1953), 32.

${ }^{56}$ Ibid., 10.

${ }^{57}$ Foster, The English Factories, 363.

${ }^{58}$ Ibid., 365.

${ }^{59}$ David Kenneth Bassett, "British 'Country' Trade and Local Trade Networks in the Thai and Malay States, c. 1680-1770," Modern Asian Studies Vol. 23, no. 4 (1989): 629.

${ }^{60}$ Diary and Consultation Book 1693-1695, entries dated December 22-23, 1695.
} 
was a royal or oligarchic monopoly, it was difficult for independent traders to accumulate enough capital for investment. He also cited the frequent tensions between the Malay ruler and his ministers, and the largely non-Malay merchant community that prospered only by the mercy of the ruler, who could revoke their privileges and dispose of their property at will. ${ }^{61}$ Kathirithamby-Wells argued that, since the ruler exercised direct control over commerce by promulgating laws, this precluded the development of autonomous urban centers with institutionalized merchant organizations similar to European commercial guilds with their own corporate laws. ${ }^{62}$ In the interests of the ruler-centered state, individual merchant interests became subordinated. ${ }^{63}$ Commercial monopolies exercised by rulers through their officials meant that trade procedures were arbitrary and trade practices did not follow any form. ${ }^{64}$

If such were the political economy and commercial ethic of Southeast Asian polities, how does one explain the periods of thriving commerce, whereby the region was a magnet to traders all over the world? I argue that the idea of "absolutist rulers" who enforced and benefited from commercial monopolies, thereby enabling them to maintain splendid courts and engage in conspicuous consumption at the expense of their subjects and foreign merchants, is but one model of political economy in the Malay world. Even then, the concept of "royal absolutism" 65 should be reexamined. It might exist in theory, but in reality, royal absolutism was limited by the nobility, the rulers' personalities, and provincial or local conditions. Provincial leaders could still temper a strong ruler such as Iskandar Muda, since control of outlying territories and the men needed to wage war came under their influence. ${ }^{66}$ For example, in 1619 , the ruler of Inderapura, unhappy with the trade conditions imposed by Iskandar Muda, requested a change of allegiance from Aceh to the VOC in Batavia, even when Inderapura was supposedly under the yoke of this mighty king. ${ }^{67}$ "Absolutist states" were fragile since, besides force of personality, wealth, and coercion, no lasting institutions or rule of law supported them.

Although one can agree that the political and commercial culture of Southeast Asian polities was ruler-centric, the political and commercial ethics of each ruler differed. One must caution against constructing a uniform picture of Southeast Asian monarchs, especially when evidence shows that the picture is more nuanced, complex, and varied depending on the polity, the time period, and even the sex of the ruler.

${ }^{61}$ John Villiers, "Doing Business with the Infidel: Merchants, Missionaries, and Monarchs in Sixteenth Century Southeast Asia," in Maritime Asia: Profit Maximisation, Ethics, and Trade Structure c. 1300-1800, ed. Karl Anton Sprengard and Roderich Prak (Wiesbaden: Harrassowitz Verlag, 1994), 153-55.

${ }^{62}$ J. Kathirithamby-Wells, "Ethics and Entrepreneurship in Southeast Asia c. 1400-1800," in Maritime Asia: Profit Maximisation, Ethics, and Trade Structure, 172.

${ }^{63}$ Ibid., 183.

${ }^{64}$ Ibid., 175.

${ }^{65}$ Anthony Reid, "Trade and the Problem of Royal Power in Aceh. Three Stages: c. 1550-1700," in PreColonial State Systems in Southeast Asia, ed. Anthony Reid and Lance Castles (Kuala Lumpur: Council of the Malaysian Branch of the Royal Asiatic Society, 1975), 47-55. See also Kathirithamby-Wells, "Restraints on the Development of Merchant Capitalism in Southeast Asia before c. 1800," in Southeast Asia in the Early Modern Era: Trade, Power, and Belief, ed. Anthony Reid (Ithaca: Cornell University Press, 1993), 125.

${ }_{66}$ Takeshi, "The World of the Adat Aceh," 62.

${ }^{67} \mathrm{~J}$. Kathirithamby-Wells, "Acehnese Control over West Sumatra up to the Treaty of Painan, 1663," Journal of Southeast Asian History 10, no. 3 (1969): 460. 
Contrary to popular claims, Aceh saw its longest period of peace and prosperity under its women sovereigns. One main reason for this was due to their style of leadership and treatment of the kingdom's orangkaya and of foreign political and commercial elite, which was different from their male counterparts' style, whose rule was more typical of the Southeast Asian monarchs described above.

Denys Lombard argues that royal-elite relations may be categorized into two models, one for strong rulers and another for weak ones. In the first, the ruler is powerful and manages his rebellious orangkaya by means of manipulation, and he deals with foreign merchants via commercial monopolies and tyranny. In the second model, when the ruler is weak, the orangkaya may tire of the ruler, arrange for his assassination/execution, and install another. ${ }^{68}$ The second model is supported by the Hikayat Aceh (an indigenous text believed to be written in Aceh in 1603), which revealed that weak kings were actually despised by the orangkaya and were usually deposed or even killed. ${ }^{69}$ While those two models aptly described royal-elite relations during the periods when male sultans ruled Aceh, ${ }^{70} \mathrm{I}$ suggest that a third model of royal-elite relations better describes the Acehnese sultanahs' rule. Whether rule based on coercion and fear was expensive and difficult to execute and maintain, or whether it was naturally offensive to or uncharacteristic of women, Aceh's women rulers preferred collaborative rule based on cooperation, which replaced the perpetual conflict that characterized royal-elite relations under earlier male kings. Such collaboration and cooperation engendered a period of peace conducive to trade. As such, the women rulers demonstrated that tension between monarchical prerogative and nobility power need not necessarily be a zero-sum game. Rather, ruler-elite relations could be mutually beneficial when characterized by interdependence and patronage.

Many scholars claim that Aceh's four women rulers were mere figureheads, placed on the throne and tolerated by the male elite since the men believed that they could hold on to their powers unencumbered. I suggest, however, that the sultanahs were not favored for their weakness. Three of the four women rulers (Kamalat Syah is the exception) remained on the throne until death not because they were tolerated, but because they were accepted. One likely reason for this was the power-sharing and decision-making processes used by the sultanahs. Such a leadership style involved the orangkaya through muafakat (consensus-building), which signalled a distinct departure from the style of previous male rulers. Saturday audiences were held regularly, many important matters were debated and discussed, and decisions were made through consensus and affirmed by all in attendance with the word "daulat" (a sign of accepting the ruler's authority). On audience days there were, of course, debates, which were arbitrated by the sultanah, since she had the final say, which was the mark of legitimacy.$^{71}$ By comparison, under Iskandar Muda, the main duty of the orangkaya was

\footnotetext{
${ }^{68}$ Denys Lombard, "The Malay Sultanate as a Socio-economic Model," in Asian Merchants and Businessmen in the Indian Ocean and the China Sea, ed. Denys Lombard and Jean Aubin (Oxford: Oxford University Press, 2000): 116-17.

${ }^{69}$ Teuku Iskandar, ed., De Hikayat Atjeh (s'.Gravenhage: Martnus Nijhoff, 1958), 96-98.

${ }^{70}$ Reid, "Trade and the Problem of Royal Power in Aceh." From 1575-1604, weak rulers were either deposed or killed. From 1604-37, the power balance shifted such that strong rulers dominated the orangkaya.

${ }^{71}$ NA, f.680R. Dagh-Register gehouden bij Pieter Sourij, 1643.
} 
simply to keep guard of the Dalam (palace quarters) every third day and night. Except for a few senior orangkaya who were summoned ad hoc to the royal presence, there were no court audiences except on state and religious occasions. ${ }^{72}$

Another characteristic feature of the women's leadership was the distribution of the country's wealth amongst the ruling elite and the elites' freedom to acquire economic wealth. This ensured the elites' support based on rewards and a sharing of the kingdom's wealth to promote a collective stake in the kingdom's survival. Some of the male rulers held to a different approach. According to Beaulieu, the surest ways for the orangkaya to court death during Iskandar Muda's reign was to be notable for "the good reputation they have among the people, and secondly their wealth." ${ }^{73}$ Such predatory behavior was not attested during the reigns of the queens. The orangkaya were free to make profits in peace. Despite tremendous pressure from the Dutch for a large share in the tin trade of Perak, the sultanah made sure that her orangkaya's right to procure tin from Perak for their own trade was protected. Jan Harmanszoon, a Dutch resident stationed in Aceh, reported that eight vessels that sailed to Perak belonged to the Acehnese orangkaya. ${ }^{74}$ In return, the orangkaya presented the customary tribute to the sultanah. ${ }^{75}$

\section{Respect for Rule of Law}

Kathirithamby-Wells argues that another characteristic feature of Southeast Asian trade was the lack of legal provision for the safety of property and person from the arbitrary powers of the ruler and administrative elite. According to Takeshi Ito, however, the law courts and justice system in Aceh were already well established by the time of Iskandar Muda. Based on observations from travelers such as Beaulieu and Mundy, and information from the Adat Aceh, the kingdom had four courts of law. One pertained to ritual, family, and inheritance; a second dealt with criminal cases; a third handled commercial law; and the last was concerned with purely religious requirements and observances, such as praying and fasting. A famous saying in Aceh goes like this: "Adat bak Poteumeureuhon, hukom bak Syiah Kuala" (customs in accordance to the sultan and law in accordance to the ulama [religious elite]).

It is important to make a distinction between a kingdom having no formal system of law and the ruler who ignored laws and traditions and ruled in an arbitrary manner. Both Iskandar Muda and Iskandar Thani were guilty of either ignoring or modifying the sultanate's syariah law. In many cases, the penalties inflicted by the rulers were harsher than the provisions of the syariah. Penalties were meted out based on traditional judicial practices, which Ito described as trial by ordeal and discretion (more often whim) of the sovereign. ${ }^{76}$ An orangkaya who requested of Iskandar Muda a deferment from going to war was instead executed by Iskandar Muda, and the

72 Ito, "The World of the Adat Aceh," 32.

${ }^{73}$ Augustine de Beaulieu, Memoirs of Admiral Beaulieu's Voyage to the East Indies (1619-1622), Drawn up by Himself, trans. from M. Thevenot's large collection of voyages in John Harris, Voyages and Travels (London: n.p., 1705), vol. 1, 257.

${ }^{74} \mathrm{NA}, \mathrm{f} .460 \mathrm{R}$. Vervolch van Atchin's dagh-register van 26 Feb-12 April 1645.

${ }^{75}$ NA, f.223V. Truijtman's Dagh-Register, 13 August 1649-November 1649.

${ }^{76}$ Ito, "The World of the Adat Aceh," 178. 
orangkaya's entire family was massacred. As if death was not punishment enough, the orangkaya and his family all had their noses, lips, ears, genitals, and bellies cut off. Both Iskandar Thani and Iskandar Muda meted out torture and death penalties on those suspected of attempting to assassinate the rulers. ${ }^{77}$ Orangkaya who were slow to offer their services were either castrated, amputated, or flogged.

Avoiding wielding arbitrary power and adhering to the rule of law were the key features of women sovereigns. Sultanah Safiatuddin tended to call upon the relevant courts to administer cases rather than mete out punishment personally based on her personal whim and caprice. In conducting trade, Sultanah Safiatuddin devolved power to the relevant authority or personnel. During Iskandar Muda's reign, protecting the ruler's interest and the overall supervision of the port were centralized in the hands of the most senior representative of the ruler, the laksamana. It was also the laksamana's duty to provide foreigners trading in Aceh protection and assistance. During the reign of Sultanah Safiatuddin, the duties of her laksamana - who was staunchly anti-Dutchwere halved, and a new position, panglima bandar, was created. The panglima bandar was tasked with matters related to trade, foreign merchants, and the west-coast pepper trade, all of which had been the sole responsibility of the laksamana. The "new" laksamana, also known as the panglima dalam, would now be in charge of only policing and security. ${ }^{78}$ In line with Safiatuddin's policy of accommodating foreign traders, including Europeans, she appointed the pro-Dutch Orangkaya Seri Paduka Seberang as panglima Bandar, and he held this post until his death in 1658. In a similar move, in 1645 the sultanah appointed her half-brother, who was the Kadhi Malik al-Adil, known to the Dutch as Lebei Kita Kali, and a good friend to the VOC, to the position of Orang Kaya Maharaja Sri Maharaja.

The policy of welcoming traders from all nations, and actively protecting their life and property, was an important feature of Aceh's women sovereigns' rule. ${ }^{79}$ This style of leadership facilitated trade and prevented capital flight. When men from the hinterlands came into the city to oppose the accession of the third queen and instigated a potentially dangerous skirmish, the sultanah made arrangements to protect the foreigners. Dampier wrote, "the Shabander sent to the Foreigners, and desired them to keep in their own Houses in the night, and told them, that whatever might happen in the City by their own civil Broyls, yet no harm should come to them. ${ }^{80}$ Sultanah Safiatuddin also granted foreigners a considerable degree of freedom. In 1668, she granted permission to the Franciscans to build a church and establish a mission in Aceh. Kamalat Syah even ensured the protection of private merchants, just as the employees of the EIC were protected. Once, the EIC requested that the queen extradite an English merchant to Madras to be put on trial for some misdeeds of which he was accused. This request was refused. In addition, the sultanah was reported to have generously provided help to a Dutch ship, which had caught fire, by offering loans and

77 Ibid., 181.

${ }^{78}$ Ibid., 291.

${ }^{79}$ It appears that Raja Ijau of Patani also took an active part in trade negotiations, protected private property, and established opportunities conducive to trade. See Francis Bradley, "Piracy, Smuggling, and Trade in the Rise of Patani, 1490-1600," Journal of the Siam Society 96 (2008): 45.

${ }^{80}$ See Dampier, Voyages and Discoveries, 145. 
other assistance. ${ }^{81}$ Under Iskandar Muda and Iskandar Thani, goods and treasures on wrecked ships were confiscated.

Collaborative rule meant a reduction of or a limitation on royal power, but it did not bring about a deterioration or decline of royal power. On the contrary, it strengthened the institution of royalty after the thirty years of Iskandar Muda's reign, which was individualistic, fragile, and arbitrary. The monopoly of power in the hands of a despotic ruler was broken by the sultanahs and distributed amongst their orangkaya, especially those who shared their policies. I argue that this limitation of monarchical power ushered in by the first sultanah brought about a stablizing institutionalization of power-sharing, which proved to be key to the kingdom's continued stability and prosperity.

\section{Discarding the Traditional Feudal-Despotic Model}

Aceh, by the end of the seventeenth century, was no longer the expanding empire it had been at the beginning, but, helped by the uneven advance of European companies' territorial and commercial empires, Aceh developed into a thriving, cosmopolitan port. Certainly, it was neither a backwater nor a subjugated state. AngloDutch companies' rivalries kept both powers in check and out of Aceh. Asian traders and European private merchants were tough commercial competitors and played important roles in Aceh, which kept the regional trade buoyant throughout the course of the seventeenth century. How best to manage that trade and foreign interest? According to Das Gupta, "at a time when the Dutch were growing into a strong power in Indonesia, Aceh needed a strong king to handle her foreign affairs. The feudaldespotic state built up by Iskandar Muda could be run only by a masterful personality, one with a great capacity for offering leadership of the traditional type. After Iskandar Muda's and Iskandar Thani's passing away, so did the glorious epoch of Aceh's history." 82 I suggest that this traditional feudal-despotic model of leadership was actually fragile and shortsighted, and the kings' attempts to monopolize commerce and resist foreign pressures only provoked political instability and disrupted commerce. Partly due to the collaborative and interdependent model of leadership based on the rule of law instituted by Acehnese women sovereigns and their accommodative foreign diplomacy, Aceh was able to remain an independent kingdom and an important regional port of call with its own autonomous commercial networks.

I do not suggest that collaboration and accommodation between royalty and local/foreign elites, respect for the rule of law, and protections for property traders pertain only to women rulers. But, as the sultanahs of Aceh demonstrated, the collaborative relations forged between women rulers and male elites were rather different from the competitive rivalries and jealousies exhibited by male rulers and male elites, and this suggests that political relations here were gendered. Furthermore, recent research on Patani by Francis Bradley reveals that the protection of private property and the establishment of opportunities conducive to trade were the hallmarks of the female ruler, Raja Ijau. ${ }^{83}$ The sultanahs of Aceh's case certainly explains Reid's

${ }^{81}$ Voyage Made by Jacob Janssen de Roy to Borneo and Atcheen, 328.

${ }^{82}$ Das Gupta, Aceh in Indonesian Trade and Politics 1600-1641, 186.

${ }^{83}$ Bradley, "Piracy, Smuggling, and Trade," 45. 
observation that the "age of commerce" in Southeast Asia coincides with the preponderance of female rule. ${ }^{84}$

${ }^{84}$ Reid, "Female Roles," 640-41. Reid cited female rulers of Bone, Pasai, Japara, Sukadana, Jambi, and Solor who were reigning when these states experienced their commercial prosperity from 1400-1680. 
